\title{
The Effect of Paikem Learning Model within Direct Instruction and Cooperative Learning Setting towards $9^{\text {th }}$ Graders Learning Mastery
}

\author{
K. Shobikhah \\ Universitas Negeri Surabaya, Surabaya, Indonesia \\ kshobikhah@gmail.com
}

\begin{abstract}
One of primary reasons of learning in the curriculum 2013 is based on strategy which is principled on PAIKEM learning. This study aimed at knowing students' learning mastery and students' response. Type of this research is Classroom Action Research that consists of 2 cycles with formative test and questionnaire as its instruments. There were 32 students participated as the sample of this study. In cycle I, mean of formative test score was $\mathbf{8 1 , 9 \%}$ and improved at $\mathbf{8 3 . 2 \%}$ in cycle II. Meanwhile, classical learning completeness in cycle I was $43.8 \%$ and improved at $93.7 \%$ in cycle II. The findings of this research were expected to give more references for Science teachers and allow the researcher to make improvements for the next research.
\end{abstract}

Keywords-active; innovative; creative; effective; joyful

\section{INTRODUCTION}

Many efforts have been conducted to improve the quality of national education. Some of them are conducting training and improvement for teacher quality, curriculum completion, procurement of books and lesson equipment, upgrading tools and infrastructure of education, and improvement of school management quality. However, many indicators of education quality denote inadequate improvement of the education quality. Government has also conducted concrete efforts to improve the quality of national education such as keeping the curriculum completion up to date, introducing new strategy, model, and novel learning approach that are adjusted to material and learners' characteristics. Thus, the way of packing learning experience which is planned by the teachers becomes the main key to improve learners' quality. An instance that recently occurred was revision of Curriculum 2013 last year [2].

One of the basic ideas of learning within mentioned curriculum is learning based on strategy principled on active, innovative, creative, effective, and joyful (PAIKEM) learning. This learning is centered on students with interesting, joyful and meaningful situation, thus able to develop students' creativity. The planned learning experience is expected to show more relations of conceptual elements then make learning process more effective and efficient. The relation of conceptual learning with the topic of relevant knowledge will create cognitive scheme, thus students will obtain integrity and totality of knowledge about real life and natural phenomenon. Such learning experiences will be well stored in students' mind and its residuals will be used during teaching and learning process in form of knowledge, expertise, and experience [1].
Student will be easy to master science and environment concepts through observation on concrete situation. By implementing this such environment-based method, students encourage their curiosity about many things in their environment. Thus, teachers can implement four pillars of education which are learning to know, learning to be, learning to do, and learning to live together through environmental learning approach packed in such way. One of active learning methods which is based on environment is PAIKEM learning (active, innovative, creative, effective, and joyful learning). This method allows students to directly engage with the environment. Thus, one example of packed learning process that can make students more active in joyful situation and achieve learning goals is PAIKEM Learning Model in Direct Instruction Setting and Cooperative Learning [1].

Based on the background and reality above, the researcher conducted this study by focusing on Static Electricity learning material. The aims of this research were to know learning completeness after using the learning model and to know students' response towards the use of the learning model.

Through this research, it is expected to give more reference and benefit for teachers, especially for Natural Science teachers to train students' capability of finding their own knowledge and skills. Students are also expected to be more active in joyful learning environment and to achieve learning goals that should be mastered so that their learning achievement could be completed and improved.

\section{METHOD}

Type of this study was Classroom Action Research which was conducted on 32 students in grade IX E SMP Negeri 1 Sumberrejo, Bojonegoro with heterogeneous degree of learning capability. The teacher was the researcher and was helped by a co-teacher as an observer.

The Classroom Action Research flow chart of Kemmis and Taggart can be seen in the picture below. 


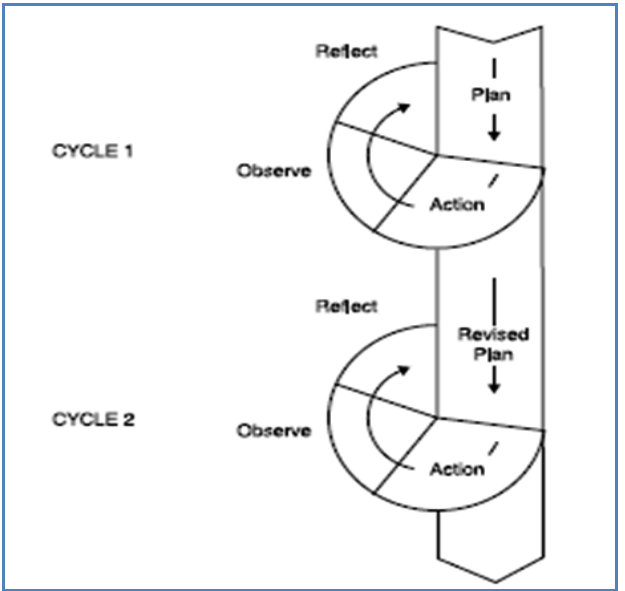

Picture 1. Classroom Action Research flow chart of Kemmis and Taggart, 1992

Data collection techniques in this research were evaluation (test) and questionnaire. Then, evaluation sheet of student learning achievement and student response questionnaire were used as the instruments. Data analysis of student learning achievement is from learning mastery of each student to achieve learning goals that was measured by a test.

In this school, students are considered completed if their score is higher than 75. Analysis of student response sheet was conducted based on percentage of the student response. Student response towards PAIKEM learning model in Direct Instruction and Cooperative Learning setting on material of Static Electricity is positive if its percentage is higher than $61 \%$ with the criteria good and very good [3].

\section{RESULT AND DISCUSSIONS}

Result of this research is simply presented in the following tables.

TABLE I. SCORING OF LEARNING ARCHIEVEMENT AT CYCLE

\begin{tabular}{|c|c|c|c|c|c|c|c|}
\hline \multirow[t]{2}{*}{ No. } & \multirow[t]{2}{*}{ Score } & \multicolumn{2}{|c|}{ Explanation } & \multirow[t]{2}{*}{ No. } & \multirow[t]{2}{*}{ Score } & \multicolumn{2}{|c|}{ Explanation } \\
\hline & & $\mathrm{T}$ & TT & & & $\mathrm{T}$ & TT \\
\hline 1. & 60 & & $\sqrt{ }$ & 17. & 80 & $\sqrt{ }$ & \\
\hline 2. & 100 & $\sqrt{ }$ & & 18. & 60 & & $\sqrt{ }$ \\
\hline 3. & 80 & $\sqrt{ }$ & & 19. & 80 & $\sqrt{ }$ & \\
\hline 4. & 80 & $\sqrt{ }$ & & 20. & 50 & & $\sqrt{ }$ \\
\hline 5. & 50 & & $\sqrt{ }$ & 21. & 50 & & $\sqrt{ }$ \\
\hline 6. & 70 & & $\sqrt{ }$ & 22. & 80 & $\sqrt{ }$ & \\
\hline 7. & 60 & & $\sqrt{ }$ & 23. & 60 & & $\sqrt{ }$ \\
\hline 8. & 60 & & $\sqrt{ }$ & 24. & 100 & $\sqrt{ }$ & \\
\hline 9. & 60 & & $\sqrt{ }$ & 25. & 70 & & $\sqrt{ }$ \\
\hline 10. & 80 & $\sqrt{ }$ & & 26. & 70 & & $\sqrt{ }$ \\
\hline 11. & 80 & $\sqrt{ }$ & & 27. & 80 & $\sqrt{ }$ & \\
\hline 12. & 60 & & $\sqrt{ }$ & 28. & 70 & & $\sqrt{ }$ \\
\hline 13. & 80 & $\sqrt{ }$ & & 29. & 70 & & $\sqrt{ }$ \\
\hline 14. & 80 & $\sqrt{ }$ & & 30. & 60 & & $\sqrt{ }$ \\
\hline 15. & 60 & & $\sqrt{ }$ & 31. & 70 & & $\sqrt{ }$ \\
\hline 16. & 90 & $\sqrt{ }$ & & 32. & 100 & $\sqrt{ }$ & \\
\hline Total & $\begin{array}{l}115 \\
0\end{array}$ & 8 & 8 & Total & 1470 & 6 & 10 \\
\hline \multicolumn{8}{|c|}{ Total score } \\
\hline \multicolumn{8}{|c|}{ Total maximum score } \\
\hline \multicolumn{8}{|c|}{$\%$ mean score of formative test $=81,9$} \\
\hline \multicolumn{8}{|c|}{$\%$ classical mastery learning } \\
\hline
\end{tabular}

$* \mathrm{~T}=$ completed, $\mathrm{TT}=$ not completed

Based on the table 1 above, student learning achievement at cycle I after implementing learning model showed by mean score of formative test Classroom IX-E SMP Negeri 1 Sumberrejo Bojonegoro that was $81.9 \%$. Based on calculation of classical learning completeness, it is known that only $43.8 \%$ student exceeded minimum standard of learning completeness (75). It means that 14 of 32 students were completed, while the other 18 students were not completed.

This result shows that at the first cycle, students were not completed classically. This can become an illustration that learning by using the implementation of PAIKEM learning model in Direct Instruction setting and Cooperative Learning was not succeeded optimally. This may be occurred because the students tend to be clumsy and not accustomed with the implementation of this model.

Therefore, cycle I was revised through an approach done by the teacher to the students to familiarize the implementation of such learning model that requires them to be more active. After the approach was implemented in the cycle II, the students were able to enjoy the learning process and understand the subject easily. Therefore, the learning goals could be achieved optimally.

TABLE II. SCORING OF LEARNING ARCHIEVEMENT AT CYCLE II

\begin{tabular}{|c|c|c|c|c|c|c|c|}
\hline \multirow[t]{2}{*}{ No. } & \multirow[t]{2}{*}{ Score } & \multicolumn{2}{|c|}{ Explanation } & \multirow[t]{2}{*}{ No. } & \multirow[t]{2}{*}{ Score } & \multicolumn{2}{|c|}{ Explanation } \\
\hline & & $\mathrm{T}$ & TT & & & $\mathrm{T}$ & TT \\
\hline 1. & 85 & $\sqrt{ }$ & & 17. & 70 & & $\sqrt{ }$ \\
\hline 2. & 85 & $\sqrt{ }$ & & 18. & 80 & $\sqrt{ }$ & \\
\hline 3. & 85 & $\sqrt{ }$ & & 19. & 85 & $\sqrt{ }$ & \\
\hline 4. & 85 & $\sqrt{ }$ & & 20. & 78 & $\sqrt{ }$ & \\
\hline 5. & 85 & $\sqrt{ }$ & & 21. & 85 & $\sqrt{ }$ & \\
\hline 6. & 85 & $\sqrt{ }$ & & 22. & 85 & $\sqrt{ }$ & \\
\hline 7. & 86 & $\sqrt{ }$ & & 23. & 80 & $\sqrt{ }$ & \\
\hline 8. & 85 & $\sqrt{ }$ & & 24. & 85 & $\sqrt{ }$ & \\
\hline 9. & 85 & $\sqrt{ }$ & & 25. & 85 & $\sqrt{ }$ & \\
\hline 10. & 85 & $\sqrt{ }$ & & 26. & 85 & $\sqrt{ }$ & \\
\hline 11. & 83 & $\sqrt{ }$ & & 27. & 85 & $\sqrt{ }$ & \\
\hline 12. & 85 & $\sqrt{ }$ & & 28. & 85 & $\sqrt{ }$ & \\
\hline 13. & 60 & & $\sqrt{ }$ & 29. & 85 & $\sqrt{ }$ & \\
\hline 14. & 85 & $\sqrt{ }$ & & 30. & 85 & $\sqrt{ }$ & \\
\hline 15. & 85 & $\sqrt{ }$ & & 31. & 85 & $\sqrt{ }$ & \\
\hline 16. & 85 & $\sqrt{ }$ & & 32. & 85 & $\sqrt{ }$ & \\
\hline Total & 1334 & 15 & 1 & Total & 1328 & 15 & 1 \\
\hline \multicolumn{4}{|c|}{ Total score } & \multicolumn{4}{|c|}{$=2662$} \\
\hline \multicolumn{5}{|c|}{ Total maximum Score } & \multicolumn{2}{|c|}{$=3200$} & \\
\hline \multicolumn{5}{|c|}{$\%$ mean score of formative test } & \multicolumn{2}{|c|}{$=83,2$} & \\
\hline \multicolumn{5}{|c|}{$\%$ classical mastery learning } & \multicolumn{2}{|c|}{$=93,7$} & \\
\hline
\end{tabular}

The table 2 above shows student learning achievement at cycle II after revision was conducted. The mean of students' formative test at IX-E SMP Negeri 1 Sumberrejo Bojonegoro was $83.2 \%$. Based on calculation of classical learning mastery, it is known that $93.7 \%$ student were already exceeded minimum standard of mastery learning (75). It means that 30 of 32 students were completed, while the other 2 students were not completed.

This result shows that the implementation of PAIKEM learning model in Direct Instruction and Cooperative Learning 
setting in Physics teaching and learning process focusing on material of Static Electricity was implemented optimally. Also, based on the revision at previous cycle and teacher approach, students were not clumsy and pay their best attention. As a result, PAIKEM learning model was easier to be applied. Because of joyful learning process, the students were more interested in the lesson and enthusiastic to participate that led them to understand the subject more easily.

With the increase of formative test mean score and learning mastery from cycle I to Cycle II, it then could be said that the implementation of PAIKEM learning model in Direct Instruction setting and Cooperative Learning in teaching and learning process of Physics at material of Static Electricity was helpful to improve students learning achievement.

TABLE III. RESULT OF STUDENT RESPONSE QUESTIONNAIRE

\begin{tabular}{|c|c|c|c|c|}
\hline \multirow[t]{2}{*}{ No. } & \multirow[t]{2}{*}{ Question } & \multicolumn{2}{|c|}{$\begin{array}{c}\text { Answer } \\
\text { Percentage } \\
(\%)\end{array}$} & \multirow[t]{2}{*}{ Criteria } \\
\hline & & Yes & No & \\
\hline 1 & P1 & 100 & 0 & $\begin{array}{l}\text { Very } \\
\text { Good }\end{array}$ \\
\hline 2 & $\mathrm{P} 2$ & 100 & 0 & $\begin{array}{l}\text { Very } \\
\text { Good }\end{array}$ \\
\hline 3 & P3 & 96,9 & 3,1 & $\begin{array}{l}\text { Very } \\
\text { Good }\end{array}$ \\
\hline 4 & $\mathrm{P} 4$ & 100 & 0 & $\begin{array}{l}\text { Very } \\
\text { Good }\end{array}$ \\
\hline 5 & P5 & 87,5 & $5^{12,}$ & $\begin{array}{l}\text { Very } \\
\text { Good }\end{array}$ \\
\hline
\end{tabular}

Based on the result of questionnaire that was given to the students at the end of learning activity, the students consider that the Natural Science learning was interesting. This is showed by $100 \%$ students answered that they were interested in Natural Science lesson. Therefore, it is important to select an appropriate learning model and strategy to maintain students' interest so they could improve their learning mastery.

The next result showed that $100 \%$ students answered that Natural Science learning activity conducted by the teacher was joyful. Thus, it can be concluded that the students enjoy the learning activity.

Further result from the questionnaire told the students' perception of whether the learning model increases their learning motivation. $96.6 \%$ students agreed with this method and $3.1 \%$ disagreed. From this result, it is known that this method might able to increase students' learning motivation in Natural Science lesson.

Furthermore, the result of the questionnaire explained the students' perception of whether the students were enthusiastic during teaching and learning process. The result shows that $100 \%$ students answered that they participated actively in the learning activity. Hence, it is known that the students were very enthusiastic and active when the learning activity occurred. These aspects can be learning indicators used by teachers to improve students' activity.

If the students are able to accept the lesson given by the teacher, researcher correlated it with learning mastery. Based on the result of the questionnaire, there were $87.5 \%$ of students have already achieved minimum criteria of learning mastery, and $12.5 \%$ of them have not. Based on these case, it is known that more than half of all students have already achieved minimum criteria of learning mastery which is 75 . This result proves that learning method implemented by the teacher gave significant contribution.

\section{CONCLUSION}

The implementation of PAIKEM learning model within the setting of Direct Instruction and Co-operative Learning on material of Static Electricity was conducted well and helped the students to achieve the expected learning objectives. It is showed by the calculation of learning mastery classically that $93.7 \%$ of students were completed and exceeded the determined learning mastery.

Based on student response questionnaire, it is obtained that $100 \%$ of students considered that Natural Science lesson was interesting, the learning activity was enjoyable, and the students participated actively during teaching and learning activity. $96.6 \%$ of students answered that the method used by teacher in teaching can increase their learning motivation on Natural Science lesson. By looking on this positive response of students, it was not surprised if $87.5 \%$ of students were completed exceeding the determined learning mastery standard.

There are some suggestions that can be followed up as the contribution of this study which are; good planning is needed in every teaching and learning process, both material and learning model need to be used in to be more varied. Thus, students did not feel bored and achieve the expected learning mastery by considering the allocated time. Socialization of PAIKEM learning model in Direct Instruction setting and Cooperative Learning is very needed to help the students improve their ability.

\section{REFERENCES}

[1] I. K. Ahmadi, PAIKEM GEMBROT, Jakarta: Prestasi Pustaka, 2011.

[2] E. L. Poerwati, Panduan memahami kurikulum 2013. Jakarta: Prestasi Pustaka, 2013.
[3] Riduwan, Skala pengukuran variabel-variabel penelitian. Bandung: Alfa Beta, 2005.

[4] G. Mettetal, "The what, why and how of classroom action research," Journal of the Scholarship of Teaching and Learning, vol. 2, no. 1, pp. 6-13, 2012. 
[5] C.A. Mertler, Action research: Teachers as researchers in the classroom. Sage, 2008.

[6] Udvari-Solner, Alice, and P. Kluth, eds. Joyful learning: Active and collaborative learning in inclusive classrooms, Corwin Press, 2007.

[7] B. Best, and W. Thomas, The creative teaching \& learning resource book, A\&C Black, 2008.

[8] N. Jackson, M. Oliver, M. Shaw, and J. Wisdom, eds., Developing creativity in higher education: An imaginative curriculum, Routledge, 2006

[9] Bangladesh Reading Association, Classroom Teaching: A Classroom Practice Based Quarterly Journal. National Conference of Teachers, 2013.

[10] R. M. Gillies, The effects of cooperative learning on junior high school students during small group learning. Learning and instruction, 14(2), 197-213, 2004.

[11] R.J. Stevens, R.E. Slavin, and A.M. Farnish, "The effects of cooperative learning and direct instruction in reading comprehension strategies on main idea identification,". Journal of Educational Psychology, vol. 83, no. 1, pp. 8-16, 1991. 